\title{
CLASSICAL CALCULATION METHODS OF COSTS AND THEIR LIMITS IN ACTUAL FRAME OF ROMANIAN ECONOMY. PRESENT TENDENCIES IN COSTS ACCOUNTANCY
}

\author{
Dragomirescu Simona-Elena, Lecturer \\ UNIVERSITY OF BACĂU \\ Solomon Daniela-Cristina, Lecturer \\ UNIVERSITY OF BACĂU
}

\begin{abstract}
:
Classical accountancy shaped and coagulated in an informational system grafted on traditional production systems, characterized by mass productions, planning etc. The powerful concentrations and grouping, economies globalization, both as offer and as demand, the new restrictions and economical opportunities and global environment technologies lead to a redefining of enterprises' objectives. From the well-known "quantity and productivity", the enterprise faced a new system of objectives: quality's increase; terms and costs decrease; productivity; flexibility. In such conditions the need of "defining new methods" appeared, the need of adapting the fundamental calculation methods, their improvement - respective the appearance of modern methods of costs calculation.
\end{abstract}

In any field where production activities are developed, where works are executed or services are performed, there exist costs. The knowing of these costs represents a necessity in any process of substantiation of decisions. The complexity of economical life under the competition conditions imposed on the market economy, leads to the increase of the purpose in information in decision making. Of its quality depends the quality of current decisions and of perspective, and implicitly, of the obtained results. The present economical environment made expensive any error in decision caused by reduced quantity of information concerning costs.

The modern enterprise management requires the permanent knowing of costs. Seen as one of the most significant indicators with the help of which the activity of an industrial firm may be appreciated, the production costs offers a series of information necessary for any leading frame, allowing the forming of a general vision of the organization. It becomes, therefore, an indispensable instrument for diagnostic, for stimulation of probable effects, of one or another from the options, decision making, and the realizations' efficiency control.

Combined to other types of instruments (budget, standards etc.), cost information becomes a powerful instrument of management control. Otherwise, in present competition economical environment, the purpose of all these instruments is "to orientate the enterprises efficiently" 1 .

In order to fulfill the support purpose of managers in decision making process, the cost should be submitted to optimization function, meaning the search of "the most advantageous compromise between performances, terms and costs"2. These suppose the identification of all means of costs reduction, especially by improving the projection of products/services/works, the improving of processes and organization.

But for the realization of a relevant pattern for costs optimization a correct "measure" of costs is imposed. By control function, the real costs are followed in order not to divert from the standards (norms) preliminary determined by optimization process. The importance of costs control was underlined for the first time by E. Smalenbach in 1909, finding the practical appliance in USA in 1920 with the occasion of

\footnotetext{
${ }^{1}$ Tabără N. - „The modernization of accountancy and management accountancy. Present facts and perspectives", Moldova Publish house, Iaşi, 2006, p. 241

2 Marian L. - „Project Management” from http://www.orizont.net/clubRO/crmd/carti/cartemarian.
} 
investigating the causes of industrial enterprises' losses. It was appreciated back then that without a permanent cost control a rational householding of the enterprise is not possible $^{3}$. In traditional practice, cost control supposes the comparison between the real complete cost (effective, post-calculated) and a standard complete cost (estimated, precalculated).

Costs represent the result of calculations developed by means of specific methods; the succession of effectuated calculations is known in specific literature and practice under the name of costs calculation. The costs calculation methods, also named methods of leading through costs, include the ensemble of processes by which the correlation between expenses and production that brought this occasion are determined.

The classical management accountancy shaped and coagulated in an informational system grafted on traditional production systems inspired by „taylorisme”, characterized by mass productions, planning etc. ${ }^{4}$ Under this situation, the used calculation methods were the classical methods of costs calculation (global method, phases method, commands method), considered as basis methods of organizing the costs measuring activity.

The cost calculated through classical methods belongs to the category of integral and absorbing cost (full-costing), the general calculation relation is:

$$
\begin{aligned}
& \mathbf{c}=\mathbf{d}+\mathbf{i} \\
& \text { where: } \\
& \mathrm{c}-\text { unitary cost; } \\
& \mathrm{d}-\text { the sum of direct expenses }
\end{aligned}
$$
afferent to product unit;

i - the sum of indirect expenses afferent to product unit;

This embodies all the production expenses, grouped on direct expenses (expenses that are identified from the beginning on products and expenses places) and indirect expenses (that can only be

\footnotetext{
3 Kilger W. - „Flexible Plankostenrechnung”, Köln, 1967, p. 80 quote from Epuran M., Băbăiţă V., Grosu C. „Bookkeeping and accountancy control”, Economic Publish house, 1999, pg. 400.

4 Dumbravă P., Pop A. - „Accountancy management in industry", Intelcredo Publish house, Deva, 1997, p. 28.
}

identified on the expenses places, not on the products too, and will therefore be assigned by procedures on the products).

Markets globalization, technological progress, new aspirations of employees, new knowledge in accountancy frame, the existence of informatics systems more and more accessible and powerful changed radically the enterprise reality.

From a relative stabile environment, simple and less varied, with an homogenous demand, stabile and quantitative, with a low concurrence, a reduced flexibility of technology and a powerful integration specific to the $19^{\text {th }}$ century, it has passed to an environment under the sign of top technologies, much more dynamic, hostile, complex, with a diversified and qualitative demand, powerful competition, short life duration of production.

The powerful concentrations and grouping, economies globalization, both as offer and demand, the new economical restrictions and opportunities and global environment technologies lead to a redefining of enterprises objectives. From the wellknown "quantity and productivity", the enterprise reached a new system of objectives:

$$
\begin{aligned}
& \text { - } \text { quality increase; } \\
& \text { - terms and costs diminishing; } \\
& \text { - productivity; } \\
& \text { - flexibility. }
\end{aligned}
$$

In present frame, in order to respond the needs of accountancy of the new production organization, the productive logic involves different products realized in small and flexible shares, increased quality, small stocks, "pulled to downstream" fluxes, polyvalent hand work, automatization. The strategy is orientated towards the fabrication of products that have value for demand, towards the insurance of activity flexibility with the purpose of adapting to environment changes, the permanent following of the costs reduction and quality amelioration.

In order to underline the production organization method evolution, from classical organization (taylorian) to an organization specific to present economic environment, and therefore necessary evolution of accountancy control, the below tables are suggestively presented. 


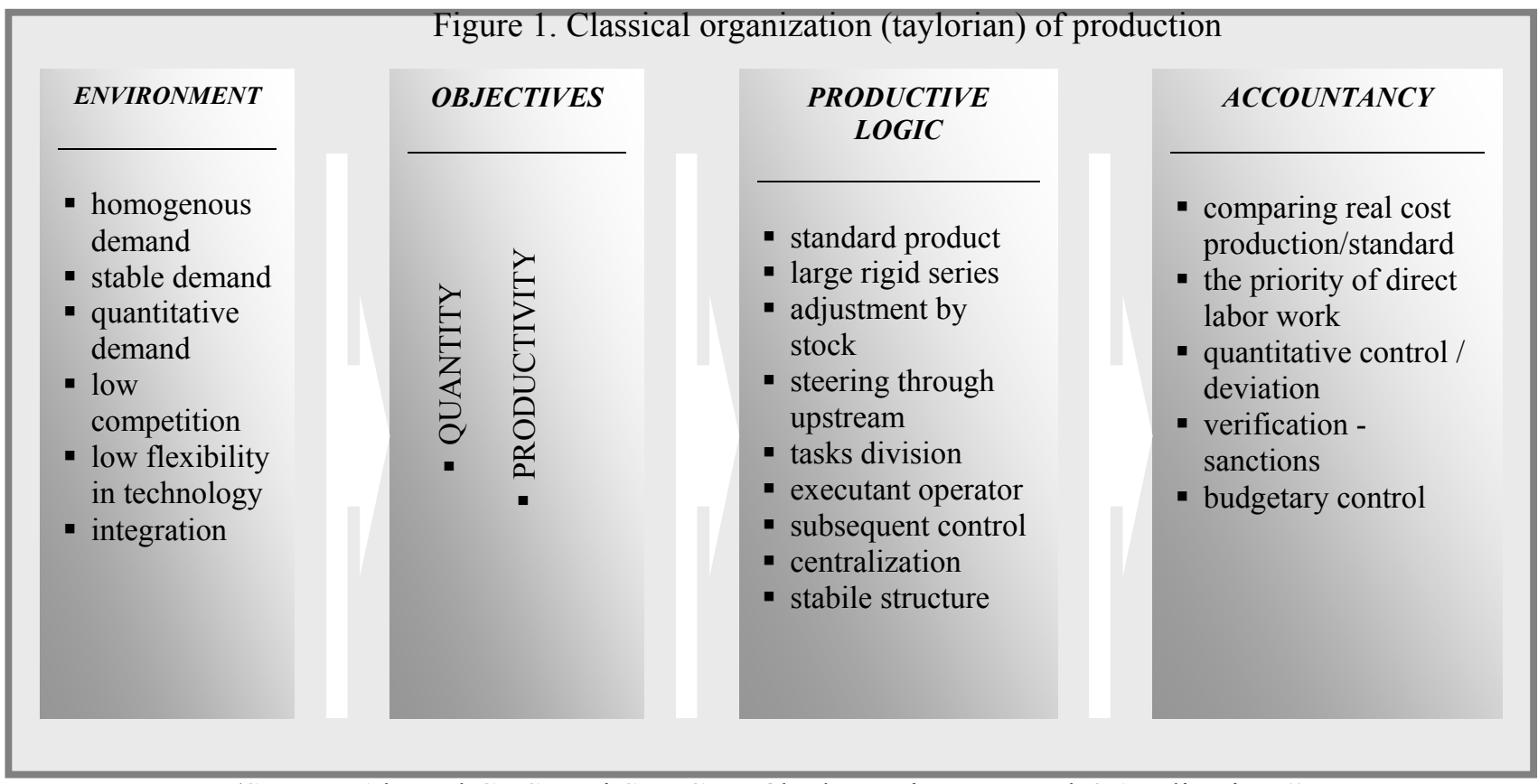

(Source: Alazard C., Sépari S.- „Contrôle de gestion. Manuel \&Applications”,

Dunod Publish house, Paris, 1996, p. 511)

Figure 2. The new production organization

\begin{tabular}{|c|c|c|c|}
\hline ENVIRONMENT & OBJECTIVES & PRODUCTIVE LOGIC & ACCOUNTANCY \\
\hline $\begin{array}{l}\text { diverse } \\
\text { demand } \\
\text { - qualitative } \\
\text { demand } \\
\text { - high } \\
\text { competition, } \\
\text { powerful } \\
\text { - short life } \\
\text { duration of } \\
\text { products } \\
\text { partnership }\end{array}$ & 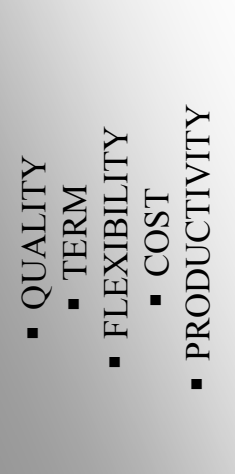 & $\begin{array}{l}\text { - varied products } \\
\text { - small shares, flexible } \\
\text { - process quality } \\
\text { - small stocks } \\
\text { - fluxes ,pulled” } \\
\text { upstream } \\
\text { - polyvalent hand } \\
\text { labour } \\
\text { - externalization } \\
\text { - automatization }\end{array}$ & $\begin{array}{l}\text { - conception cost } \\
\text { - quality cost } \\
\text { - logistic costs } \\
\text { - collaboration } \\
\text { costs } \\
\text { - maintaining costs }\end{array}$ \\
\hline
\end{tabular}

(Source: Alazard C., Sépari S.- „Contrôle de gestion. Manuel \&Applications”,

Dunod Publish house, Paris, 1996, p. 511)

Under these conditions, the choice of calculation method of cost becomes difficult. Traditional methods become obsolescent. Their appliances in present economic frame highlight a series of limits:

- it presents the inconvenience that, through their appliance the effective cost of products is obtained, but with a big delay in proportion to the moment of developing of economic processes that have generated it;

- the calculation having on its basis these methods does not constitute an operative instrument of following the expenses of production, the information offered by post-calculation allowing only posterior analysis, periodical, by comparison to costs budget;

- it does not assure a specific system of costs control and analysis, and, therefore, the necessity of elaboration according to the same methodology of two rows of calculation concerning the production cost appears. A former row of calculation is the one preceding the development of production process, materializing in costs budget (with its different sections), ant the latter is made after the end of the 
production process, to which is referred, on the basis of accountancy management data. The elaboration of the two rows of calculations creates the premises of comparison, periodically, no doubt, of the effective indicators with the ones predicted in the budget.

- the practicing of absorbing classical costs produces a phenomenon of "subvention" between the complete costs afferent to different products/services that have a common basis of distribution. This phenomenon makes some products/services to increase or decrease their costs, in the detriment or advantage of other products/services ${ }^{5}$. The types of "subvention effects" would be, for instance: effects owed to activities variety and costs heterogeneity; effects owed to series size; effects connected to investments for work productivity increase.

There should also be underlined the fact that the costs structure changed in majority, the direct costs weight decreasing in the favor of the indirect ones. As consequence, the distribution of indirect costs using as distribution basis direct costs lost any relevance. Also, indirect costs become more technical costs resulted from quality, studies, maintenance, methods etc.

In countries with a developed market economy, the classical methods of calculation of costs were replaced by modern methods, such as the Just In Time method, ABC method (Activity Based Costing), Target-Costing method etc.

Just In Time method departs from the Japanese principles of organization and management, founded on concepts of productivity and flexibility, where production is "pulled downstream" by clients' commands, by an effective demand and not "pushed upstream" according to production programs elaborated according to adjusted sells predictions, eventually, by stocks level.

\footnotetext{
${ }^{5}$ Ionaşcu I., Filip A.T. and Stere M. - ,Accountancy control”, ASE Publish house, Bucureşti, 2001, p. 48.
}

Also connected to new organization of production system, the integration of all production steps from the three fundamental cycles is appointed: CONCEPTION $\rightarrow$ FABRICATION $\rightarrow$ DISTRIBUTION.

The possibility of improving any process in what the cost, quality, and term is concerned is befriended especially by this global vision upon all the activities necessary to productive process.

\section{- ABC method (Activity Based} Costing) is founded on a new, more realist, cutting of enterprises, starting from the chain notions of value and transverse organizing, on activities.

Hugues Boisvert ${ }^{7}$ underlined the passing from tasks efficiency to processes reconception. Therefore, the author started from the definition of the process that represents a network of activities connected by a commune objective, a chain of activities necessary for delivery of a product or service. On its turn, an activity is considered an ensemble of tasks. The reconception of processes sends to the manner of exerting the activities (adding, modification, suppressing) that compose these processes, to reorganization of connections between these activities and their coordination. Thus, it is brought again under discussion the present organization of enterprise and instauration of a new pattern of action. ${ }^{8}$

The Basis principle of $\mathrm{ABC}$ method is the distribution less arbitrary of indirect expenses, in concordance to the appeal to effective products, calculation objects, enterprise's processes or activities. The cost calculated by this method is more pertinent. An enterprise consumes resources in order to perform tasks, which may be regrouped on activities, and activities form, on their turn, products. Therefore, a product is the result of an ensemble of processes, respective of

\footnotetext{
${ }^{6}$ Epuran M., Băbăiță V., Grosu C. - „Bookkeeping and accountancy control", Economic Publish house,, 1999, p. 385.

${ }^{7}$ Boisvert H. - „De la comptabilité à la gestion par activités", Revues International de Gestion, vol. 18, nr. 4, November 1993, p. 7-8.

8 Guinea A.F. - „Evolutions and involutions in management accountancy”, „Bookkeeping and accountancy control” Magazine, nr. 8, 2006, p. 43.
} 
sequences of complementary activities. ${ }^{9}$ In other words, products consume activities, and the activities consume resources.

Costs are allocated to activities on the basis of variables that express the consumption low, respective explicative factors of costs variation (that starts the activity), also called costs inductors and work units. Costs inductors represent the basis of activity's costs distribution between the products that consumes it, for these a unitary cost being calculated.

The calculation of the cost of a product supposes the summing of all direct and indirect expenses, the latter representing shares form the activities consumed established with regard to the number of work units consumed (inductors) and their unitary cost.

Target-Costing method follows the products costs correlated with their life cycle, especially with the resources consume imposed in conception phase. From this phase even, a management's major concern is constituted by product's competition in terms of price. Target-costs, seen as management step, are based on the rule according to which market dictates selling costs and not the enterprises' costs do it. ${ }^{10}$ It is obvious that the enterprise will want to ensure a certain profit during the life cycle of the specific product. In order to build the profit it should go from price to cost, the target-cost, an estimated cost, being calculated by deduction from the imposed selling price of awaited profit average. Analyzing costs on the whole product's life duration, it is understandable that from the imposed selling price should be covered on long term all enterprise's costs, both direct and indirect, both fixe or variable, therefore the target cost is a complete one. The selling price, being an imposed one, represents a limit that cannot be surpassed, and if the limit cannot be respected by enterprise it results that the respective product is not viable.

\footnotetext{
${ }^{9}$ Bouquin H.- ,Management accountancy” (translation and introduction study Neculai Tabără), TIPOMOLDOVA, Iaşi, 2004, p. 184.

${ }^{10}$ Ebbeken K., Possler L., Ristea M. - „Calculation and costs management", Teora, Bucharest, 2000, p. 379.
}

Specific literature ${ }^{11}$ presents other two methods as well:

- Life Cycle Costing used especially in planning phase, to estimate the product's cost on its life period.

Kaizen - Costing used for identification of cost improvement opportunities during the phase production.

In conclusion, the loss of pertinence of traditional cost calculation systems is due, mainly, to the existence of a clash between the present pattern of enterprise's control and the pattern of analysis centers, and to the difference between the composition pattern of real cost and the image given by management accountancy.

Under these circumstances, the need of "defining new methods" ${ }^{12}$, appeared, the need of adapting the fundamental calculation methods, their improvement - respective the appearance of modern methods of costs calculation. As consequence, some enterprises gave up classical methods, adapting evolved methods, more adapted to economical environment requires. Other enterprises adapted a series of indicators in order to measure the performances directly, for instance, by means of dashboards, than indirectly by means of costs. But, no matter the applied methods, the accountancy control should allow the development of activity and decision making in such manner that the enterprises would attain their goals. And cost is an important instrument of accountancy control that, determined as correct as possible in order to reflect reality, sustains managers in the process of piloting the enterprise.

\footnotetext{
11 Albu N., Albu C. - „Instruments of performance management", vol. I., Management accountancy, Economic Publish house, Bucharest, 2003, p. 240.

12 Tabără N. - „The modernization of accountancy and management accountancy. Present facts and perspectives", Moldova Publish house, Iaşi, 2006, p. 248.
} 


\section{References:}

[1] Alazard C., Sépari S, Contrôle de gestion. Manuel \& Application, Editura Dunod, Paris, 1996;

[2] Albu N., Albu C., Instrumente de management al performanței, vol. I., Contabilitate de gestiune, Editura Economică, Bucureşti, 2003;

[3] Boisvert H., De la comptabilité à la gestion par activités, Revues International de Gestion, vol. 18, nr. 4, noiembrie 1993;

[4] Bouquin H., Contabilitate de gestiune (traducerea şi studiul introductiv Neculai Tabără), Editura TIPOMOLDOVA, Iaşi, 2004;

[5] Dumbravă P., Pop A., Contabilitatea de gestiune în industrie, Editura Intelcredo, Deva, 1997;

[6] Ebbeken K., Possler L., Ristea M., Calculația şi managementul costurilor, Editura Teora, București, 2000;

[7] Epuran M., Băbăiță V., Grosu C., Contabilitate şi control de gestiune, Editura Economică, 1999;

[8] Guinea A.F., Evoluții şi involuții în contabilitatea de gestiune, Revista „Contabilitate şi control de gestiune", nr. 8, 2006;

[9] Ionaşcu I., Filip A.T. şi Stere M., Control de gestiune, Editura ASE, București, 2001;

[10] Marian L., Managementul proiectelor, pe http:// www.orizont.net / clubRO/ crmd/ carti/ cartemarian.

[11] Tabără N., Modernizarea contabilității şi controlului de gestiune. Actualităţi şi perspective, Editura TipoMoldova, Iaşi, 2006. 